KURAS Tat'yana Leonidovna, Cand.Sci. (Hist.), Associate Professor of the Chair of Justice, Law Institute, Irkutsk State University(1 Karla Marksa St, Irkutsk, Russia,664003; tanya_kuras@mail.ru)

KURAS Sofia Leonidovna, Cand.Sci. (Hist.), Associate Professor of the Chair of Customs Affairs and Jurisprudence, Irkutsk State Transport University (15 Chernyshevskogo St, Irkutsk, Russia, 664074; kuras@list.ru)

\title{
THE ACTIVITIES OF THE JUDICIAL CHAMBERS OF THE RUSSIAN EMPIRE AND BODIES OF THE PRISON DEPARTMENT ON THE PAGES OF COMMEMORATIVE BOOKS
}

Abstract. The author examines commemorative books as a source of study of the judiciary and the prison authorities of the Russian Empire in the second half of the $19^{\text {th }}$ and early $20^{\text {th }}$ century. The authors analyze quantitative and personal composition of the officials of these bodies, their changes over the years and reveal significant differences in the placement of information about employees of these bodies in the commemorative books of various provinces and regions.

Keywords: commemorative books, court, Court Chamber, prison, prison department

\section{УДК 351.74}

ГУРЛЕВ Игорь Валентинович - доктор технических наук, главный научный сотрудник Академии управления МВД России (125171, Россия, г. Москва, улица 3. и А. Космодемьянских, 8; gurleff@ mail.ru)

\section{ОБЕСПЕЧЕНИЕ БЕЗОПАСНОСТИ НА ТРАНСПОРТЕ В РОССИЙСКОЙ ИМПЕРИИ (1797-1917)}

Аннотация. В статье автор показывает эволюцию внутренних транспортных коммуникаций в России с конца XVIII до начала XX в.: от речного, морского и дорожного - к железнодорожному транспорту. Приведены официальные исторические документы, на основе которых власти страны создавали органы обеспечения безопасности на транспорте. Автор исследует деятельность полиции и жандармских полицейских управлений железных дорог, которые обеспечивали не только безопасность, но и бесперебойную работу сети железных дорог. На основе документов Временного правительства автор показывает негативное влияние Февральской революции, которая привела к ликвидации системы безопасности на транспорте.

Ключевые слова: водный, сухопутный, железнодорожный транспорт, жандармское полицейское управление

$\mathrm{B}$ первые пути сообщения в Российской империи выделились в особую отрасль управления при императоре Павле I.

27 февраля 1797 г. (все даты указаны по старому стилю. - Aвm.) Павел I дал указ Сенату (закон № 17.848) «О препоручении водяных коммуникаций во всей Империи в главное ведение и управление Действительного Тайного Советника Сиверса; и о доставлении ему всех нужных по сей части сведений», которым Я.Е. Сиверсу поручалось подготовить предложения об улучшении всех водных коммуникаций в империи 1 .

1 Полное собрание законов Российской империи (ПСЗРИ). Т. XXIV. С 6 ноября 1796 по 1798. СПб. 1830. C. 504-505. 
Ровно через год, 28 февраля 1798 г., именным указом Павла І главному директору водяных коммуникаций Я.Е. Сиверсу (Указ об учреждении департамента для произведения и правления всех дел по водяным коммуникациям; о бытии ему под ведомством Сената и произвождении дел по Регламенту Коллегий; закон № 18.403) был утвержден штат департамента, бюджет, выделены помещения и основано депо всех гидравлических карт по всей империи. Департамент водяных коммуникаций приравнивался к коллегии ${ }^{1}$.

20 ноября 1809 г. манифестом Александра I (закон № 23.996) было создано Учреждение об управлении водяными и сухопутными сообщениями, согласно которому Департамент водяных коммуникаций преобразовывался в орган центрального управления путями сообщения - Дирекцию водных и сухопутных коммуникаций ${ }^{2}$.

В манифесте говорилось, что «распространение земледелия и промышленности, возрастающее население столицы и движение внутренней и внешней торговли превосходят уже меру прежних путей сообщения». Это вызвало к жизни новые структуры: Экспедицию устроения дорог, Управление водными и сухопутными сообщениями, Корпус инженеров путей сообщения и институт при нем.

На новое ведомство возлагалась обязанность управления всеми водными и значительными сухопутными путями сообщения России. Одновременно с манифестом было утверждено Учреждение об управлении водяными и сухопутными сообщениями, в соответствии с которым вся территория страны была разбита на 10 транспортных округов. В каждом из них назначался специальный директор, при котором были сформированы подразделения «полицейских команд дирекции водных и сухопутных коммуникаций». Таким образом, в 1809 г. возникла транспортная полиция, задачами которой являлось обеспечение безопасности на речном и морском транспорте. Главная дирекция находилась в Твери, правления округов - в губернских городах. Например, Сибирь входила в 10-й округ путей сообщения, правление которого располагалось в городе Тобольске. Полицейские команды формировались окружным директором водных и сухопутных коммуникаций, подчинялись ему и действовали независимо от местной администрации, городской и сельской полиции. В задачу полицейских транспортных команд входило обеспечение безопасности на речном и дорожном транспорте, сопровождение и предотвращение хищений грузов.

Полицейские подразделения Дирекции водных и сухопутных коммуникаций, образованные в районах расположения золотых и платиновых приисков на Урале, в Западной и Восточной Сибири, назывались горно-полицейской стражей.

В промышленных районах России действовала фабрично-заводская полиция.

Приморские города нуждались в других направлениях правоохранной деятельности, и там была создана портовая полиция.

K первой половине XIX в., начиная с постройки Карлом Бердом в 1815 г. достаточно примитивного первого русского парохода, относится начало появления пароходств в России.

28 мая 1820 г. Александр I утвердил доклад главного директора путей сообщения Бетанкура «О новом образовании Главного Управления Путей Сообщения» (закон № 28.291), в соответствии с которым Дирекция водных и сухопутных

\footnotetext{
1 ПСЗРИ. Т. ХХV. 1798-1799. СПб. 1830. С. 109-110.

2 ПСЗРИ. Т. ХХХ. 1808-1809. СПб. 1830. С. 1305-1339.
} 
коммуникаций была преобразована в Главное управление путей сообщения с целым рядом структурных подразделений.

21 марта 1836 г. Николай І утвердил положение (закон № 9009) «Об учреждении Общества Акционеров для сооружения железной дороги от Санктпетербурга до Царского села с продолжением до Павловска». В компании «твердо решились вести построение таким образом, чтобы дорога от Фонтанки до Царского села была открыта, если можно, 1-го Октября текущего 1836 года» ${ }^{1}$.

Длина первой в России железной дороги из Санкт-Петербурга в Царское Село составила 24 версты (около 25,6 км). Руководил строительством австрийский инженер Франц Герстнер. Железная дорога строилась с шириной колеи 1829 мм (6 футов). Почти все необходимое для железной дороги закупалось за границей: были приобретены рельсы, стрелочные переводы, крепления, подвижной состав.

Первоначально Царскосельская железная дорога была проложена от СанктПетербурга до Царского Села, а позже была продлена до дачного городка Павловска, при этом общая протяженность трассы выросла до 27 км. Первая пробная поездка поезда с конной тягой между Царским Селом и Павловском состоялась 27 сентября 1836 г.

Тожественное открытие движения по Царскосельской дороге после построения вокзалов, паровозного депо и других необходимых сооружений состоялось 30 октября (11 ноября) 1837 г.

29 октября 1839 г. Николай І утвердил указ (закон № 12818) «О преобразовании Департамента Главного Управления Путей Сообщения и Публичных зданий», в результате чего было образовано Главное управление путей сообщения 2 .

1 (13) ноября 1851 г. первый поезд отправился в путь по крупнейшей тогда в Европе железнодорожной магистрали из Санкт-Петербурга в Москву.

26 января 1857 . император Александр II утвердил указ Сенату (закон № 31448) «О сооружении первой сети железных дорог в России». Одновременно были утверждены Положение об основных условиях для устройства первой сети железных дорог в России и Устав Главного Общества Российских железных дорог ${ }^{3}$.

В России началось массовое железнодорожное строительство с привлечением значительного числа людей. Одновременно бурно расцвели коррупция и казнокрадство и, как следствие, несоответствие качества железных дорог предъявляемым требованиям. Росла криминальная активность строительных рабочих. Они совершали преступления против личности, растаскивали материалы. Возникла проблема обеспечения общественного порядка и безопасности при строительстве железных дорог, а затем и обеспечения общественного порядка и безопасности при их эксплуатации.

Необходимо было решить, кто должен обеспечивать правопорядок на железной дороге. Были выделены необходимые средства, но в связи с тем, что железные дороги проходили по территориям различных губерний, нередко на большом удалении от населенных пунктов, общая полиция не могла выполнять эти задачи. Поэтому потребовалось создание специальных отрядов железнодорожных жандармов.

При строительстве первых железных дорог в середине XIX в. полицейский надзор за порядком на них осуществлялся жандармскими эскадронами и

\footnotetext{
1 ПСЗРИ-2. Т. ХІ. Отд. первое. 1836. СПб. 1837. С. 225-229.

2 ПСЗРИ-2. Т. ХVІ. Отд. первое. 1839. СПб. 1840. С. 798-799.

3 ПСЗРИ-2. Т. ХХХІІ. Отд. первое. 1857. СПб. 1858. С. 72-92.
} 
командами, находившимися в оперативном подчинении департамента Главного управления путей сообщения.

В 1860-х гг. жандармские эскадроны и команды были преобразованы в управления. 27 июля 1861 г. Александр II утвердил Положение о жандармских полицейских управлениях Санкт-Петербургско-Варшавской и МосковскоНижегородской железных дорог (закон № 37289), в котором говорилось, что «Для полицейского надзора по С.-Петербурго-Варшавской и МосковскоНижегородской железным дорогам учреждается особое для каждой линии Полицейское Управление, из чинов Корпуса Жандармов». На полицейские управления (ПУ) возлагались функции надзора и безопасности на железных дорогах: наблюдение за точным исполнением рабочими и подрядчиками взаимных обязательств, обеспечение сохранности имущества и порядка на железнодорожных станциях, рассмотрение жалоб рабочих, подрядчиков, служащих, проезжающих и проживающих на железных дорогах, контроль за паспортами, обеспечение «благочиния» и др. ${ }^{1}$

15 июня 1865 г. указом Александра II (закон № 42194), данным Сенату, Главное управление путей сообщения было преобразовано в Министерство путей сообщения ${ }^{2}$.

Кроме военного министра и шефа жандармов, ПУ также подчинялись Министерству путей сообщения через инспекторов соответствующих дорог, безопасность которых они обеспечивали.

Согласно действовавшим в то время нормативным актам, сотрудники ПУ имели специфические обязанности и пользовались правами наружной полиции, принимая участие в охране общественного порядка, предупреждении и пресечении нарушений «общественного благочиния» и обеспечении безопасности на железных дорогах. Кроме того, жандармы были обязаны наблюдать за целостностью путей и дорожных сооружений, не допускать к ним посторонних, следить за чистотой и опрятностью носильщиков на вокзалах, а также проверять качество продуктов в станционных буфетах и др.

Основными силами «благочиния и порядка» были сотрудники патрульнопостовой службы. Патрулировались депо, мастерские, склады, подъездные пути. Один раз в месяц жандармы были обязаны обойти всю территорию обслуживаемого участка.

По признанию руководства корпуса жандармов, успехи жандармерии в борьбе с кражами грузов были весьма скромными. Частично это объяснялось отсутствием сыскной полиции и опыта оперативной работы. Кроме того, жандармам категорически запрещалось носить гражданскую одежду. Основной работой жандармерии считалось патрулирование. Полномочия жандармских патрулей были почти всеобъемлющими: проверка исправности люковых запоров и дверей вагонов, пресечение допуска к погрузке посторонних, присутствие при наложении пломб и замков при отправлении поезда, проверка в присутствии понятых сохранности груза при каждом подозрительном случае, выезд на место происшествия и т.д. Жандармы были обязаны требовать от начальника станции сосредоточенного размещения вагонов с грузом при длительных стоянках, обеспечения их охраны и освещения места стоянки.

31 декабря 1866 г. Александр II дал именной указ (закон № 44071) военному министру «Об обязанностях и подчинении Жандармских Полицейских Управлений железных дорог», в соответствии с которым полицейские управления были изъяты из ведения Министерства путей сообщения и полностью

\footnotetext{
1 ПСЗРИ-2. Т. ХХХVІ. Отд. второе. 1861. СПб. 1863. С. 195-197.
}

2 ПСЗРИ-2. Т. XL. Отд. первое. 1865. СПб. 1867. С. 644-645. 
подчинены шефу жандармов. Вместе с тем в указе отмечалось: «..обязать чинов Полицейских Управлений железных дорог: а) исполнять все предписания Министра Путей Сообщения, обращенные к ним непосредственно, и б) исполнять все законные требования инспекций железных дорог, непротиворечащие их обязанностям, в смысле водворения нарушенного порядка, а равно успешного и безостановочного движения всех поездов» 1.

По сравнению с предыдущими ПУ на транспорте функции жандармских полицейских управлений железных дорог (ЖПУ ж.д.) были расширены - они должны были исполнять также обязанности общей полиции, пользуясь всеми присвоенными ей правами. Район действия ЖПУ ж.д. простирался на всю территорию, отведенную под железные дороги, на все находившиеся на этой полосе постройки и сооружения. ЖПУ ж.д. занимались «охранением внешнего порядка, благочиния» и общественной безопасности.

Порядок жандармского полицейского надзора на железных дорогах устанавливал, что в ведении каждого железнодорожного жандармского управления должен находиться участок пути в 2000 верст. В свою очередь, это расстояние делилось на участки по 200 верст, находившиеся в ведении жандармского отделения.

16 марта 1867 г. высочайшим повелением Александра II были утверждены структура и штаты ЖПУ ж.д. Штат каждого железнодорожного жандармского управления состоял из начальника, его адъютанта и начальников отделений, а также до 300 унтер-офицеров. Хотя железнодорожные жандармские управления как составные части корпуса жандармов являлись органами политической полиции и финансировались из бюджета военного министерства, они не только обеспечивали военную охрану железнодорожных путей и сооружений (мостов, туннелей, вокзалов, депо и т.д.), но и обязаны были вести борьбу с уголовными преступлениями на территории железнодорожных сооружений и в полосе отчуждения железнодорожных путей, главным образом с хищениями грузов. Соответственно, они пользовались и всеми правами общей полиции.

Вследствие бурного развития железнодорожной сети ЖПУ ж.д. к началу XX в. стали самыми крупными подразделениями корпуса жандармов, превзойдя по численности личного состава все остальные части корпуса вместе взятые. Основной задачей жандармской железнодорожной полиции считалась борьба с хищениями грузов на железной дороге и предотвращение транспортных происшествий. В своей деятельности транспортная жандармерия руководствовалась Полицейскими железнодорожными правилами и наблюдала за их исполнением. Этот акт определял весь порядок работы железных дорог - от формирования поездов до способа подачи аварийных сигналов. Поэтому жандармы следили за исправностью пути, чистотой на перронах, правильностью составления грузовой документации, сохранностью пломб на дверях вагонов, имели право отстранить от работы поездную бригаду в случае ее нетрезвости и т.д. - словом, представляли собой как бы вторую администрацию дороги.

Во главе ЖПУ ж.д. стояли начальники на правах командиров полков в чине генерал-майоров или полковников, назначались они приказами по Отдельному корпусу жандармов. Личный состав жандармских подразделений состоял главным образом из офицеров и унтер-офицеров. Рядовых почти не было, т.к. младшие чины комплектовались преимущественно из прошедших срочную службу в кавалерийских частях - жандармы считались принадлежащими к кавалерии. Комплектование офицерского состава осуществлялось преимущественно офицерами гвардейской кавалерии. Жандармы получали

1 ПСЗРИ-2. Т. XLI. Отд. второе. 1866. СПб. 1868. С. 532. 
оклады значительно более высокие, чем офицеры в полках, и, кроме того, в их распоряжении находились различные специальные ассигнования, о трате которых не требовался отчет.

В структуре МВД Российской империи и Департамента полиции, по свидетельству современников, жандармская железнодорожная полиция была самым дисциплинированным и профессионально подготовленным подразделением.

27 июня 1867 г. Александр II утвердил положение «Об устройстве речной полиции» (закон № 44774), согласно которому в Санкт-Петербурге был создан специализированный орган охраны правопорядка на водных магистралях столицы. Речная полиция входила в состав столичного полицейского управления и была призвана поддерживать общественный порядок, бороться с преступностью на акваториях. Она также обеспечивала надзор за точным исполнением действующих постановлений по судоходству и охране порядка как на воде, так и в береговых сооружениях; порядок следования судов для их беспрепятственного прохождения по рекам и каналам столицы; контроль за своевременной погрузкой и выгрузкой товаров на берег; принятие мер к спасению утопающих людей и погибающих судов; наблюдение за исправным содержанием паровых и гребных судов, предназначенных для случаев наводнения; общественный порядок на водах. Одновременно были утверждены штат и бюджет речной полиции ${ }^{1}$.

В Российской империи специализированная речная полиция была организована в трех регионах: Санкт-Петербурге, Нижнем Новгороде и Рыбинске. Деятельность указанных подразделений имела различное нормативно-правовое регулирование, а их структура и функции были неодинаковыми.

19 мая 1871 г. Александр II утвердил Правила о порядке действий чинов Корпуса жандармов по исследованию преступлений (закон № 49615), которые закрепили порядок действия чинов ЖПУ ж.д. по расследованию преступлений в зоне их ответственности с предоставлением им всех прав «общей полиции» ${ }^{2}$.

25 июня 1882 г. Александр III утвердил указ (закон № 992) «О распределении прав и обязанностей по управлению Отдельным Корпусом Жандармов между Министром Внутренних Дел и одним из Товарищей его, с присвоением сему последнему наименования Командира означенного Корпуса». Таким образом, общее руководство, или высшее «начальствование над отдельным корпусом жандармов» осуществлял министр внутренних дел Российской империи, ставший одновременно шефом жандармов 3 .

К концу ХІХ в. строительство железных дорог приняло столь интенсивный характер, что стало не хватать рабочих. И тогда по решению правительства в марте 1894 г. на строительство были направлены лица, отбывавшие наказание в местах лишения свободы. Вполне естественно, что эта категория лиц часто совершала преступления, а потому требовала к себе особого внимания со стороны полиции.

С учетом увеличения числа железных дорог возрастало и число ЖПУ ж.д, которые учреждались в рамках одной или нескольких железных дорог. В целом, железнодорожная полиция решала задачи «охранения внешнего порядка, благочиния и общественной безопасности в районе действия жандармских полицейских управлений железных дорог» и защиты интересов железнодорожного

\footnotetext{
1 ПСЗРИ-2. Т. XLII. Отд. первое. 1867. СПб. 1871. С. 1053-1054.

2 ПСЗРИ-2. Т. ХLVI. Отд. первое. 1871. СПб. 1874. С. 591-594.

3 ПСЗРИ-3. Т. ІІ. 1882. СПб. 1886. С. 343-344.
} 
транспорта от криминального воздействия посторонних лиц и от незаконных действий самих железнодорожников.

Однако сотрудников не хватало, и в течение 1900-1905 гг. Николай II принял более 20 решений (законов) о создании новых управлений или об увеличении численности существующих ЖПУ ж.д. ${ }^{1}$

В 1903 г. рассматривалось предложение о создании жандармской железнодорожной конно-полицейской стражи, но по финансовым соображениям от его реализации отказались. Зато некоторое распространение в последующие годы получило использование специально обученных сыскных собак, так называемых собак-сыщиков.

Вплоть до 1905 г. ЖПУ ж.д. не принимали непосредственного участия в производстве дознаний по государственным преступлениям, в политическом сыске и наблюдении. Однако революционное движение 1905 г. и его дальнейший рост, активная роль, которую сыграли железнодорожные рабочие и служащие в придании Октябрьской стачке в сентябре-октябре 1905 г. всероссийского и всеобщего характера, заставили правительство принять срочные меры и привлечь сотрудников ЖПУ ж.д к борьбе с революционными выступлениями.

На сотрудников ЖПУ ж.д были возложены обязанности производства дознаний обо всех «преступных действиях» политического характера, совершенных в полосе отчуждения железных дорог. При производстве дознаний начальники ЖПУ ж.д. подчинялись начальникам губернских жандармских управлений. В результате ЖПУ ж.д. стали выполнять также функции политической полиции. На железных дорогах был создан секретно-агентурный надзор, что обязывало ЖПУ ж.д. иметь собственную агентуру.

В начале 1917 г. в России насчитывалось 75 губернских и областных жандармских управлений, 33 ЖПУ ж.д., в состав которых входили 322 жандармских отделения: 3 дивизиона, 1 конная жандармская команда, 2 пеших жандармских команды, 2 портовых и 21 крепостная жандармская команда.

К февралю 1917 г. Россию захлестнула волна революционного движения. 27 февраля 1917 г. революционные отряды разгромили жандармское отделение Николаевского вокзала в Санкт-Петербурге.

В результате Февральской революции 2 марта 1917 г. власть в стране перешла к Временному правительству.

В принятом в первых числах марта документе (дата не указана) «5. О назначении Министров общественного Кабинета и о программе его деятельности» говорится, что «в своей настоящей деятельности Кабинет будет руководствоваться следующими основаниями: ...5) замена полиции народной милицией с выборным начальством, подчиненным органам местного самоуправления» ${ }^{2}$.

10 марта 1917 г. Временное правительство приняло постановление «8. Об упразднении Департамента полиции и об учреждении временного управления по делам общественной милиции» ${ }^{3}$.

17 апреля 1917 г. было принято Постановление «80. Об учреждении милиции» и утверждено «Временное положение о милиции». Вместе с тем в п. VI Постановления было отмечено, что «впредь до подготовки опытных кадров речной милиции речная полиция в городах: Петрограде, Нижнем

1 ПСЗРИ-3. Т. ХХ. 1900. Отд. І. СПб. 1902. Законы: 18464; 18609; 19043; 19046; 19157; 19163; $19199 ;$ 19138; Т. XXI. 1901. Отд. І. СПб. 1903. Законы: 19688; 19696; 20066; 20433; 20585; 20612; 20650; 20665; 20669; 20720; 20828; 20866; Т. XXV. 1905. Отд. І. СПб. 1908. Законы: 26168; 26896; 27078; 26783.

2 Сборник указов и постановлений Временного Правительства. Вып. 1. 27 февраля - 5 мая 1917. Петроград. 1917. С. 7-8.

3 Там же. С. 27. 
Новгороде и Рыбинске продолжает исполнять свои обязанности, состоя в ведении Начальника городской милиции» ${ }^{1}$.

Уже к середине марта в столицах (Санкт-Петербург, Москва, Варшава) процесс расформирования железнодорожной полиции практически был завершен, однако в связи с объективной необходимостью обеспечения безопасности на железнодорожном транспорте на территориях некоторых губерний она просуществовала под тем или иным названием до ноября 1917 г.

GURLEV Igor' Valentinovich, Dr.Sci. (Tech.Sci.), Chief Researcher of the Academy of Management, Ministry of Internal Affairs of Russia (8 Zoe and Alexander Kosmodemyanskih St, Moscow, Russia, 125171; gurleff@mail.ru)

\title{
ENSURING TRANSPORT SECURITY IN THE RUSSIAN EMPIRE (1797-1917)
}

Abstract. The article considers the evolution of internal transport communications in Russia from the end of the $18^{\text {th }}$ to the beginning of the $20^{\text {th }}$ century: from river, sea and road transport to railways. The author presents official historical documents on the base of which the authorities of the country created transport security agencies. The article studies the work of police and gendarme police departments of the railways, which provided not only security, but also smooth operation of the railway network. Based on the documents of the Provisional Government, the author shows the negative impact of the February revolution, which led to the elimination of the transport security system. Keywords: water, land, railway transport, gendarme police department

\footnotetext{
${ }^{1}$ Там же. С. $185-192$.
}

\section{УДК 94(575.4)}

ВОЛКОВ Иван Васильевич - кандидат политических наук, доцент; ученый секретарь Общества изучения истории отечественных спецслужб (Россия, г. Москва; ivolga54@gтаil.com)

\section{ОБ ОТЧУЖДЕНИИ ЗЕМЕЛЬ ПОД ЖЕЛЕЗНОДОРОЖНОЕ СТРОИТЕЛЬСТВО В PУCCKOM TYPKECTAHE}

\begin{abstract}
Аннотация. Статья посвящена исследованию вопроса изьятия царской властью земель под железнодорожное строительство в Средней Азии. Законодательные документы доказательно свидетельствуют, что отчуждение земель осуществлялось на основании именных царских указов и материального возмещения изъятого из казны. Автор считает, что ускорение экономического развития региона при русской власти явилось главным условием цивилизационной модернизации жизни коренного населения дореволюционной Средней Азии.
\end{abstract}

Ключевые слова: Русский Туркестан, железнодорожное строительство, отчуждение земель, «туземное» население, царская власть

$\mathrm{B}$ ажнейшим условием экономического перерождения Средней Азии стало появление в регионе российских железных дорог. Они стали основой проникновения в Туркестан капиталистических отношений и качественно новой цивилизации. 